\title{
CD39 Regulation and Functions in T Cells
}

\author{
Eleonora Timperi ${ }^{1, *(D)}$ and Vincenzo Barnaba ${ }^{2,3, *}$ \\ 1 Department of Immunology, PSL Research University, INSERM U932, Institut Curie, 26, rue d'Ulm, \\ 75005 Paris, France \\ 2 Department of Internal Clinical Sciences, Anaesthesiology and Cardiovascular Sciences, Sapienza Università \\ di Roma, 00161 Rome, Italy \\ 3 Laboratory Affiliated to Istituto Pasteur Italia-Fondazione Cenci Bolognetti, 00161 Rome, Italy \\ * Correspondence: eleonora.timperi@curie.fr (E.T.); vincenzo.barnaba@uniroma1.it (V.B.)
}

\section{check for} updates

Citation: Timperi, E.; Barnaba, V. CD39 Regulation and Functions in $\mathrm{T}$ Cells. Int. J. Mol. Sci. 2021, 22, 8068. https://doi.org/10.3390/ ijms22158068

Academic Editor: Cintia S. De Paiva

Received: 28 June 2021

Accepted: 23 July 2021

Published: 28 July 2021

Publisher's Note: MDPI stays neutral with regard to jurisdictional claims in published maps and institutional affiliations.

Copyright: (c) 2021 by the authors. Licensee MDPI, Basel, Switzerland. This article is an open access article distributed under the terms and conditions of the Creative Commons Attribution (CC BY) license (https:// creativecommons.org/licenses/by/ $4.0 /)$.

\begin{abstract}
CD39 is an enzyme which is responsible, together with CD73, for a cascade converting adenosine triphosphate into adenosine diphosphate and cyclic adenosine monophosphate, ultimately leading to the release of an immunosuppressive form of adenosine in the tumor microenvironment. Here, we first review the environmental and genetic factors shaping CD39 expression. Second, we report CD39 functions in the $\mathrm{T}$ cell compartment, highlighting its role in regulatory $\mathrm{T}$ cells, conventional $\mathrm{CD}^{+} \mathrm{T}$ cells and $\mathrm{CD} 8^{+} \mathrm{T}$ cells. Finally, we compile a list of studies, from preclinical models to clinical trials, which have made essential contributions to the discovery of novel combinatorial approaches in the treatment of cancer.
\end{abstract}

Keywords: adenosine; CD39; CD73; regulatory T cells; conventional CD4 ${ }^{+} \mathrm{T}$ cells; $\mathrm{CD}^{+} \mathrm{T}$ cells; single nucleotide polymorphism; targeting therapy

\section{Adenosine Pathway and CD39/CD73 Expression in the Tumor Microenvironment}

CD39 is an ectoenzyme (ecto-nucleotide triphosphate diphosphohydrolase 1, encoded by ENTPD1 gene) belonging to the family of ectonucleotidases which comprises ecto-5'-nucleotidase (NT5E)/CD73, CD38/NADase, NAD glycohydrolases, nucleoside diphosphate kinase, ecto-nucleotide pyrophosphate phosphodiesterases (E-NPPs), ectonucleoside triphosphate diphosphohydrolases (ENTPDases), and adenylate kinases [1-3].

Pioneer studies described CD39 as adenosine triphosphate (ATP) diphosphohydrolase in vascular/endothelial cells, defining its crucial role in thromboregulation $[4,5]$. Together with the enzymatic activity of CD73, CD39 is responsible for a cascade in which ATP is converted into adenosine diphosphate (ADP) and cyclic adenosine monophosphate (cAMP), ultimately generating extracellular adenosine. The broad immunosuppressive effects of extracellular adenosine have been widely reported [6], and the immunosuppressive activities adenosine-mediated have been thoroughly reviewed $[7,8]$.

The adenosine pathway occurs via type 1 purinergic receptors $\left(A_{1}, A_{2 A}, A_{2 B}, A_{3}\right)$, which are $G$ protein-coupled receptors (GPRCs). $A_{1}$ and $A_{3}$ receptors inhibit adenylate cyclase and cAMP generation. They are generally described as immune-promoting adenosine receptors [9]. In contrast, $A_{2 A R}$ and $A_{2 B R}$ are typically associated with a high level of immunosuppression, triggering intracellular cAMP accumulation $[6,7,10]$. In line with this, genetic deletion of the $A_{2 A}$ receptor was shown to induce tumor rejection in mice, providing a critical link between the adenosine pathway and tumor immunity [10]. Although the $A_{2 B}$ receptor has been described in tumor cells [11], both the $A_{2 A}$ and $A_{2 B}$ receptors are largely expressed in different immune cells, including myeloid and lymphoid compartments [12-14]. Under normal physiological conditions, concentrations of extracellular ATP (eATP) are negligible in tissue, i.e., 10-100 nM. However, under inflammatory conditions, and in response to diverse stimuli such as hypoxia/tissue injury or in tumors, high eATP levels $(1-50 \mu \mathrm{M})$ may be detected $[9,11,15]$. 
Various cell types may release ATP into the microenvironment through deputed channels (i.e., pannexin or hemichannel connexins), or as result of necrosis from dying or stressed cells. Robust inflammatory signals are provided by high eATP levels through the engagement of $\mathrm{P} 2$ receptors (P2Y and P2X families), which, in turn, are critical for the activation of both innate and adaptive immune responses. The $\mathrm{P} 2 \times 7$ receptor has been described as the most important in the context of inflammation [16]. It has been reported to be highly expressed in granulocytes, macrophages, dendritic cells, B and T cells, and in particular, in $\mathrm{CD}^{+} \mathrm{T}$ cells expressing FOXP3, the master regulator of the development and function of regulatory T cells (Tregs) [17]. The production of IL-18 and IL-1 $\beta$ as active forms is mediated by eATP via the P2X7 receptor, which triggers NLRP3 inflammasome activation [18].

CD39 upregulation is therefore an efficient mechanism developed by tumors to escape antitumor strategies by depleting the immune-stimulatory eATP in the tumor microenvironment (TME).

CD39 has been observed to be highly expressed in different human tumor types, such as renal cell carcinoma, ovarian cancer, sarcoma cancer, breast cancer, lymphoma, bladder cancer, colon cancer and melanoma [19-22]. Tumor cells can overexpress CD39 compared with normal cells; however, elevated levels have been also reported in endothelial cells, cancer-associated fibroblasts (CAF) and several immune subpopulations, particularly, natural killer (NK) cells, tumor-associated-macrophages (TAM) and tumor-infiltrating lymphocytes (TILs) including Tregs and CD8 ${ }^{+} \mathrm{T}$ cells [23-28]. High CD39 expression is considered a marker of poor outcome and disease progression [29-31].

eATP and extracellular adenosine levels are also regulated by CD73 expression, the ecto-enzyme converting AMP into adenosine. CD73 is frequently expressed in human tumors, particularly in tumor cells, CAF and endothelial cells, but also in myeloid cells, NK cells and T cells [32-35]. Most data described a strong correlation between elevated CD73 levels and unfavorable clinical outcomes, as was observed for CD39 [36-39]. Through CD39 and CD73 blockade, likely limiting the conversion of ATP/AMP into adenosine, many mouse, human and in vitro studies showed inhibition of both tumor growth and metastasis formation, generally associated with an increase of NK and/or CD8 T cell immune-mediated antitumor responses [21,25,33,40-44].

\section{CD39 Expression and Functions in Conventional CD4 ${ }^{+} \mathrm{T}$ Cells and Tregs}

CD39 has been primarily described as a $\left(\mathrm{FOXP}^{+}\right)$Treg marker [24], whose hydrolysis of extracellular ATP is crucial in terms of their immunosuppressive functions. In vitro and in vivo studies on ENTPD1-deficient $\left(\mathrm{CD} 39^{-/-}\right)$mice demonstrated an impairment in Treg suppressive functions. Accordingly, adenosine formation in murine and human Tregs is mediated by the coexpression of CD39 and CD73 [24,45]. Adenosine-triggered signals may increase intracellular cAMP levels, resulting in the transactivation of ENTPD1 promoter, that, in turn, increases and stabilizes CD39 expression in Tregs [46]. The eATP signaling pathway, mediated by P2X7 receptors and phospho-Erk, may interfere with the differentiation and suppressive functions of Tregs. Indeed, eATP depletion in the TME limits the activation of HIF- $1 \alpha$ factor, which is mainly responsible for the ubiquitination and degradation of FOXP3 [45]. In line with this, reduced numbers of $\mathrm{CD}_{3} 9^{+} \mathrm{FOXP3}^{+}$Tregs were observed in patients affected by multiple sclerosis (MS), indicating that CD39 expression in Tregs is critical in controlling inflammatory autoimmune disorders [24]. In contrast, circulating levels of $\mathrm{CD} 39^{+} \mathrm{CD} 25^{+}$Tregs were elevated in cancer patients $[47,48]$, while their low levels were associated with improved relapse-free survival in melanoma patients [49]. Accordingly, CD39 ${ }^{+}$Treg frequency and adenosine-mediated immunosuppression were significantly increased in head and neck patients [50]. Importantly, elevated levels of CD39, often concomitant with elevated levels of other suppressive/activation markers (i.e., OX40, PD1, CTLA-4) [51,52], were observed in tumor-infiltrating Tregs, which generally occurred in elevated number and frequency in solid tumors $[51,53]$. All these observations suggest the key role of CD39 in attenuating immune responses in cancer. 
CD39 may also be expressed in conventional (c) $\mathrm{FOXP3}^{-} \mathrm{CD}^{+} \mathrm{T}$ cells. For example, in squamous cell carcinoma patients, $\mathrm{CD} 39^{+} \mathrm{CCD}^{+} \mathrm{T}$ cells revealed tumor-specific antigen reactivity [54]. Interestingly, CD39-expressing $\mathrm{CCD}^{+} \mathrm{T}$ cells have often been associated with T helper (Th) 17 effector functions. Th17 cells are known to promote chronic inflammation and regulate commensal bacteria in the gut. Consistent with this, eATP production by commensal bacteria may support Th17 differentiation. Comparably, P2X7 receptor may favor Th17 conversion from Tregs [55]. On the other hand, CD39-expressing Th17 cells are associated with increased IL-10 production, and CD39+ ${ }^{+}$Th17 cells predict poor clinical outcome in cancer patients [56]. Accordingly, CD39 ${ }^{+}$tumor-infiltrating Tregs may produce IL-17, in contrast to CD39- tumor-Tregs, in colon cancer patients [51], supporting the hypothesis that $\mathrm{CD} 39^{+} \mathrm{IL}-17$-producing cells play a determining role in cancer.

\section{CD39 Expression and Functions in $\mathrm{CD}^{+} \mathrm{T}$ Cells}

CD39 expression in $\mathrm{CD}^{+} \mathrm{T}$ cells has been recently reported. Pioneer studies described CD39 as a marker of exhaustion. Gupta and colleagues demonstrated that CD39 expression identified terminally exhausted virus-specific $\mathrm{CD}^{+}{ }^{+} \mathrm{T}$ cells in HCV and HIV chronic infections [57]. More recently, Canale and colleagues reported that tumor-infiltrating CD39 ${ }^{\text {high }} \mathrm{CD}^{+} \mathrm{T}$ cells exhibited low TNF$-\alpha$, IFN- $\gamma$ and IL-2 production. CD39 expression was accompanied by coinhibitory receptors (i.e., LAG3, TIGIT, PD1, TIM3, 2B4) and associated with tumor growth [28]. CD39 ${ }^{+} \mathrm{CD} 8^{+} \mathrm{T}$ cells have been found in invaded lymph nodes and metastases [28], and are generally associated with poor survival, as in clear cell renal carcinoma [58]. In 2018, an elegant paper described, for the first time, that CD39 selectively marked tumor (neoantigen)-specific $\mathrm{CD} 8^{+} \mathrm{TILs}$, whereas those $\mathrm{CD}^{-} 9^{-}$comprised bystander $\mathrm{CD}^{+} \mathrm{T}$ cells which are able to recognize a wide range of viral epitopes [23]. Interestingly, $\mathrm{CD} 39^{+} \mathrm{CD} 8^{+}$TILs were enriched in genes associated with cell proliferation and exhaustion, and displayed reduced TCR diversity, as typically observed in chronically antigen-stimulated $\mathrm{T}$ cell expansion [23]. In line with this evidence, many papers have described $\mathrm{CD} 39^{+} \mathrm{CD} 8^{+}$TILs as tumor-antigen specific and reactive cells $[59,60]$. These polyfunctional and protective roles are mostly associated with CD103 co-expression in several cancer types $[23,44,60,61]$. CD103 is indeed a marker of tissue resident memory $\mathrm{CD}^{+} \mathrm{T}$ cells, and its expression is frequently correlated with good progression, positive outcome and better survival in several cancers $[60,62,63]$.

However, several groups have suggested that $\mathrm{CD} 39$-expressing $\mathrm{CD} 8^{+} \mathrm{T}$ cells showed regulatory properties [64,65]. Although $\mathrm{CD} 8^{+}$Tregs have been widely studied in the past 30 years, their markers have not yet been fully elucidated [64]. Our group and others showed that CD39 is potentially involved in mediating the suppressive abilities of tumorinfiltrating $\mathrm{CD}^{+}$Tregs. Isolated $\mathrm{CD} 39^{+} \mathrm{CD} 8^{+} \mathrm{T}$ cells were indeed found to be capable of suppressing T cell proliferation in vitro [44]. Moreover, CD39 counteraction significantly inhibited the suppressive capacities of $\mathrm{CD} 8^{+}$Tregs, highlighting its key role in mediating suppressive functions [66], as also described for $\mathrm{CD}^{+}$Tregs [24].

Taken together, these apparently contrasting data suggest that CD39 is upregulated by antigen-driven, activated $\mathrm{CD} 8^{+} \mathrm{T}$ cells in an attempt to regulate excessive immunopathologies by its intrinsic capacity to provide stimulated $\mathrm{T}$ cells with a suppression function. This regulatory mechanism may be beneficial in conditions in which it is necessary to switch off immune responses, for example, following recovery from infection. In contrast, it would also be detrimental in tumor conditions, i.e., by providing suppression capacity to tumor-specific $\mathrm{CD} 39^{+} \mathrm{CD} 8{ }^{+} \mathrm{T}$ cells that are chronically stimulated by tumor antigenic persistence.

\section{CD39 Regulation by Cytokines}

While the vast majority of the data describe CD39 expression and its functions associated with an ex vivo phenotype in TME, less is known about the mechanisms by which it is upregulated in $\mathrm{FOXP}^{+}$Tregs, $\mathrm{CCD} 4^{+}$and $\mathrm{CD}^{+} \mathrm{T}$ cells under specific circumstances. 
Circulating $\mathrm{cCD}^{+} \mathrm{T}$ cells show negligible levels of CD39. In contrast, blood Tregs from healthy donors (HD) may express around $0-5 \%$ of $\mathrm{CD} 39^{+}$cells; this frequency may increase in cancer patients, reaching about $5-20 \%[53,67]$.

CD39 frequency may be highly increased in TI-Tregs and TI-cCD4 ${ }^{+}$cells compared to its circulating counterparts, suggesting that peculiar factors in TME can contribute to CD39 levels.

In vitro studies have shown that the combination of TCR engagement and IL-2 may increase CD39 expression. Additionally, TGF- $\beta$ was found to be particularly likely to induce the expansion of $\mathrm{CD} 39^{+}$Tregs, supporting the hypothesis that tumor-derived factors play important roles in CD39 upregulation in Tregs [67]. Comparably, the TGF$\beta /$ SOX4 signaling pathway, with the participation of ROS-driven autophagy, was shown to mediate CD39 expression in Tregs [68]. IL-27 signaling was found to directly drive CD39 expression in Tregs by a STAT-1-dependent mechanism in mice studies. Indeed, mice lacking the IL-27 EBI3 subunit or IL-27R $\alpha$ failed to display CD39 upregulation on tumor-infiltrating Tregs [69]. IL-35 has also been described as being responsible for CD39 induction in Tregs [70].

Consistent with $\mathrm{CD} 39$ levels in peripheral $\mathrm{CCD}^{+} \mathrm{T}$ cells, negligible $\mathrm{CD} 39$ levels are observed in circulating $\mathrm{CD} 8^{+} \mathrm{T}$ cells in both healthy subjects and cancer patients [28,44]. However, the frequency of CD39 ${ }^{+} \mathrm{CD} 8^{+}$TILs is enhanced in many cancer types $[23,28,44,60]$.

As for $\mathrm{FOXP3}^{+}$Tregs and $\mathrm{CCD} 4^{+} \mathrm{T}$ cells, upon TCR stimulus in vitro, blood $\mathrm{CD} 8^{+} \mathrm{T}$ cells overexpress CD39 in both healthy subjects and cancer patients [28,71], as well as in murine $\mathrm{CD} 8^{+} \mathrm{T}$ cells [72]. Although TCR engagement was sufficient to upregulate CD39, IL6 and IL-27 exposure further promoted CD39 expression in both human and murine CD8 ${ }^{+}$ T cells [28]. IL-6 has been also shown to induce CD39 expression in tumor-infiltrating NK cells in esophageal squamous cell carcinoma, suggesting a broad IL-6-mediated mechanism regulating CD39 expression in several immune cells [73]. Among the factors involved in CD39 upregulation in CD8 ${ }^{+} \mathrm{T}$ cells, IL-12 and IL-4 have been described as important players [65].

\section{CD39 Regulation by Genetic Factors}

In humans, the number of circulating $\mathrm{T}$ cells is, in part, heritable, underlying the importance of genetic elements in balancing immune responses [74]. Recently, a complex network of genetic variants governing the regulation of immune cell levels in health and disease has been defined [75]. Additionally, the genetic structure of Tregs, which is largely determined by several single nucleotide polymorphisms (SNPs), has also been described [76].

SNP at the position rs10748643, is responsible for different CD39 expression levels in T cells. For the first time, this observation was made in Tregs, in which the A allele determined low CD39 levels, compared to G subjects, that instead showed higher CD39 levels. Subjects with the GG variant correlated with better control of inflammatory responses and with less IL-17 and IFN- $\gamma$ production by pathologic effector cells, as compared with AA subjects [77]. In line with this finding, SNP associated with low CD39 expression was linked to increased susceptibility to Crohn's disease [78]. Other studies have described the impact of rs10748643 SNP on Tregs in regulating autoimmune disorders, infections and cancers [51,77,79-81], as well as in graft-versus host disease in a humanized mouse model [81]. A different CD39 gene polymorphism, associated with low CD39 expression, was additionally correlated with slower HIV progression [82]. Remarkably, the different genetic variants determined the frequency of tumor-CD39high Tregs, potentially balancing the immunosuppressivemediated Treg responses in colon rectal cancers [51].

SNP at position rs_10748643 was also correlated with a lower or absent CD39 cell surface expression in $\mathrm{CCD}^{+} \mathrm{T}$ cells. AA subjects were less predisposed to upregulate $\mathrm{CD} 39$ by anti-CD3/CD28 stimulation, as compared with AG or GG individuals, thus influencing an in vivo $\mathrm{T}$ cell response to vaccination. Indeed, individuals with the AA variant showed higher specific-T cell response to different strains of the influenza virus [83]. 
Interestingly, CD39 resulted a negative checkpoint inhibiting the generation of $\mathrm{T}$ follicular helper (Tfh) cells. The study demonstrated that BCL6 (lineage-determining transcription Tfh factor) was able to inhibit CD39 expression. Additionally, increased Tfh frequencies were observed in subjects with a SNP preventing/limiting ENTPD1 transcription. Accordingly, by reducing CD39 expression, Tfh generation and germinal responses were enhanced [84].

Even if rs_10748643 SNP has been widely studied in Tregs and cCD4 ${ }^{+} \mathrm{T}$ cells, we recently observed the same impact on $\mathrm{CD}^{+}$TILs. We demonstrated that circulating $\mathrm{CD}^{+} \mathrm{T}$ cells from AA individuals were less susceptible to CD39 upregulation upon TCR engagement in vitro. Moreover, SNP influenced CD39 levels in TI-CD8 ${ }^{+}$cells, balancing $\mathrm{CD}^{+} \mathrm{T}$ cell responses in colon rectal cancer [44].

\section{Targeting Adenosine Pathway, CD73 and CD39 as Anti-Tumor Strategy}

An increase in the number of clinical trials targeting adenosine pathway components has been observed in recent years. Data about the efficacy of this approach are still limited, since most trials are ongoing or are in the early phases of development.

Each member of the adenosine signaling pathway could be potentially considered a distinct therapeutic opportunity; however, each could be susceptible to compensatory effects, leading to the accumulation of adenosine. Importantly, the unique feature of CD39 inhibition is a dual impact, i.e., in maintaining low pro-inflammatory eATP levels and reducing adenosine accumulation; indeed, pharmacologic inhibition of CD73-mediated AMP processing or inhibition via $\mathrm{A}_{2 \mathrm{~A}}$ address only the reduction of adenosine accumulation. Of note, CD39 inhibition demonstrated antitumor efficacy as single-agent, whereas the use of two different anti-CD73 antibodies or an $\mathrm{A}_{2 \mathrm{~A}}$ small-molecule inhibitor only delayed tumor growth in MC38 mouse models. Additive affects have therefore been observed when targeting both CD39 and CD73 in combination [85], or when combining anti-CD73 with $\mathrm{A}_{2 \mathrm{~A}}$ small-molecule inhibitors [33].

The inhibition of CD73 and CD39 has similar effects on T cells. Different studies have shown that anti-CD73 antibodies could restore antitumor $\mathrm{CD} 8^{+} \mathrm{T}$ cell responses, as well as reducing the suppressive activities of Treg; see Figure 1 [42,86,87].

Anti-CD73 small molecule inhibitors were shown to reduce ovarian cancer progression and increase survival in mice [86]. Similarly, Häusler and colleagues demonstrated that in human primary ovarian cancer cells and cell lines, CD73 and/or CD39 siRNA or small-molecule inhibitors enhanced NK-mediated cytotoxic T-cell activity and CD4 ${ }^{+} \mathrm{T}$ cell proliferation [22]; see Figure 1. Because CD73 is expressed in many host cell types such as endothelial cells or CAFs, CD73 inhibition could have nonhematopoietic effects, i.e., a broad effect which is less observed when CD39 is targeted. Accordingly, many groups have collectively demonstrated that CD73-deficient mice are resistant to growth and metastasis formation in immunogenic tumors, and that CD73 deficiency in both hematopoietic and nonhematopoietic cells is required to limit tumor growth $[43,88,89]$. It is noteworthy that host CD73 deficiency or blocking were shown to increase tumor antigen specific-T cell homing to tumors. It has been demonstrated that high levels of CD73 in endothelial cells limit the migration of tumor-specific $\mathrm{CD}^{+} \mathrm{T}$ cells at the tumor site [89].

Most findings about the role of CD39 in antitumor immunity and tumor growth were the result of studies on CD39-deficient mice. Genetic depletion of Entpd1 in mice reduced metastatic lesions by active NK-mediated surveillance $[27,90]$. 


\section{A FOXP3+ Treg cells}

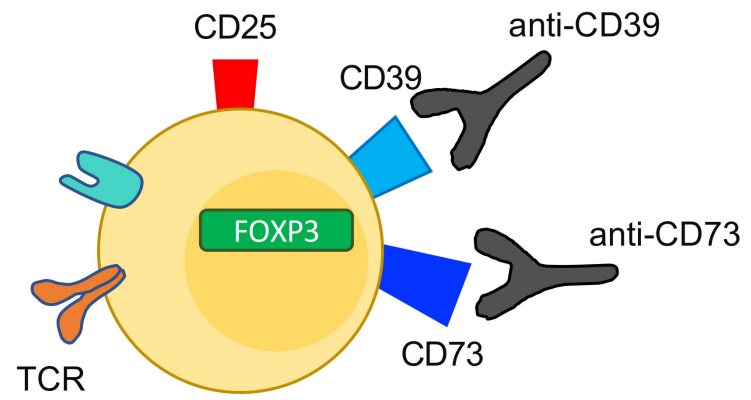

anti-CD39/anti-CD73

$\downarrow$ Treg suppression

\section{B $\mathrm{CD}^{+} \mathrm{T}$ cells}

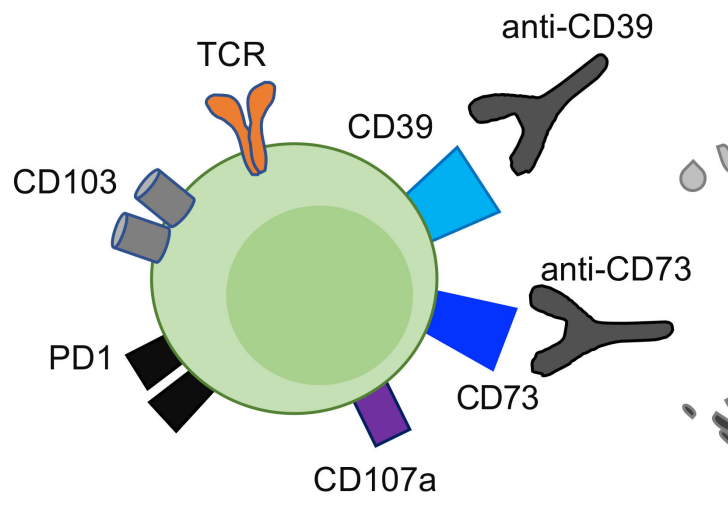

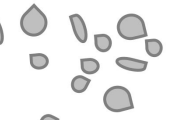

0

IFN- $\gamma$
T effector functions

T cell cytotoxicity

T cell proliferation

C conventional $\mathrm{CD} 4^{+} \mathrm{T}$ cells

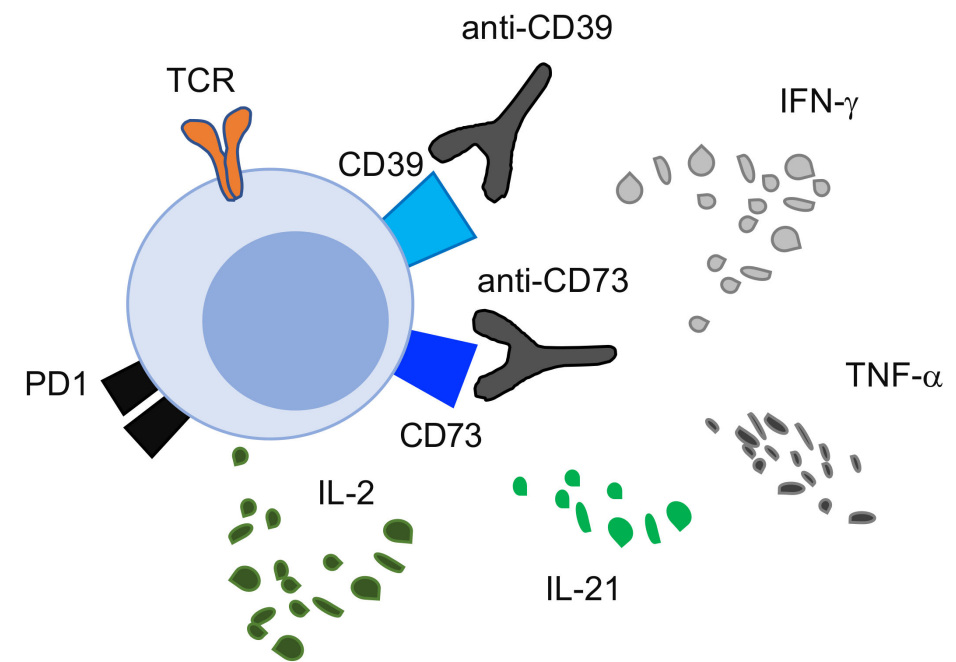

Figure 1. Effects of targeting CD39 on T cells. (A) CD39 or CD73 blocking by pharmacological compounds (i.e., POM1 and ARL7156 or small-molecule inhibitors) or by using antibodies in in vivo systems decreases the suppressive activities of FOXP3 ${ }^{+}$Treg cells. (B) Targeting CD39 or CD73 in CD8 T cells effects an increase in effector and cytotoxic T cell functions, mediated by IFN- $\gamma$ and TNF- $\alpha$ production and CD107a upregulation. (C) Targeting CD39 or CD73 in CD4 T cells increases Th1 cytokine (IFN- $\gamma$, TNF- $\alpha$ and IL-2) and IL-21 production, which (was recently found to be) is responsible for B cell differentiation. 
More recently, other researchers have shown the effects of monoclonal antibodies targeting CD39 in several tumor models [26,85]. Anti-CD39 treatment suppressed metastasis by enhancing IFN- $\gamma^{+}$and/or CD107a ${ }^{+}$TI-NK cells in a lung cancer mouse model [26]. In line with this, antibodies targeting human CD39/CD73 membrane-associated or soluble forms were shown to reduce tumor growth by boosting T-cell antitumor responses in syngeneic mouse models implanted in different tumor cell lines (MC38, MCA205, B16F10) [85]. An additional study confirmed that triggering the eATP-P2X7 pathway by anti-CD39 improved tumor T cell infiltration and rescued anti-PD1 resistance by exhausted T cells [25]. These studies were then corroborated by the use of ectonucleotidase inhibitors, POM1 and ARL7156, i.e., pharmacological compounds which are frequently used in in vivo and in vitro studies $[44,91,92]$. Although data derived from these pharmacological compounds should be interpreted with caution due to their lack of ectonucleotidase inhibitor specificity, many findings showed that ARL67156 and/or POM-1 increased IL-21 and IL-2 production in $\mathrm{CCD}^{+} \mathrm{T}$ cells by restoring their ability to induce $\mathrm{B}$ cell differentiation [83] (Figure 1). Additionally Tfh generation and germinal center responses were enhanced by reducing CD39 expression via cAMP/PKA/p-CREB pathway inhibition [84]. Inhibition of CD39 activity via the ARL CD39 inhibitor contributed to protecting $\mathrm{CCD}^{+} \mathrm{T}$ cells from apoptosis and to increasing effector $\mathrm{CCD}^{+} \mathrm{T}$ cell differentiation and survival [83]. Recently, we described that POM1-treated CD8 ${ }^{+}$TILs restored IFN- $\gamma$ and CD107a and decreased PD1 expression, compared to $\mathrm{CD} 39^{-} \mathrm{CD} 8^{+}$. CD39 inhibition mediated by POM1 may therefore shift the $\mathrm{CD}^{+} \mathrm{T}$ cell balance toward a functional effector phenotype in cancer [44] (Figure 1).

Given the abundant expression of CD39 on Tregs, they are certainly one of the major targets of CD39 inhibition. Firstly, CD39-null mice showed an impairment in Treg suppressive activities in melanoma and colon cancer models in both in vitro and in vivo experiments $[93,94]$. POM1-mediated CD39 inhibition was able to abrogate Treg suppressive capacitates by diminishing NK and T cell inhibition [94] (Figure 1). Similarly, knock down of CD39 by using a CD39 antisense oligonucleotide in vivo reduced the number of tumor-infiltrating CD39+ Tregs; as a consequence, the ratio of $\mathrm{CD}^{+} \mathrm{T}$ cells to Tregs in tumors was significantly improved [40].

\section{CD39 Targeting for Immunotherapy Strategies}

Targeting CD39 by knockdown of the Entpd1 gene led to the dysregulation of many physiological processes in mice, including glucose tolerance, angiogenesis, thromboregulation, coagulation and inflammatory responses. CD $39^{-/-}$null mice showed impaired hepatic insulin sensitivity, accompanied by high levels of insulin, IL-6, IL-1 $\beta$, TNF- $\alpha$ and IFN- $\gamma$ in the serum. These data suggest a robust link between CD39 and inflammation in regulating metabolic responses. Consistently, a mouse model with total CD39 deletion showed high susceptibility to murine colitis, confirming the key role of CD39 in regulating susceptibility to inflammatory bowel diseases $[78,95,96]$. In line with this, an interesting observation was made in human siblings with a homozygous mutation in the ENTPD1 gene. They were characterized by a stop-codon mutation, which presented low ATP activity and low AMP production; they went on to develop neurological and gastrointestinal disorders [97]. Given the impact of CD39 deletion in vivo resulting in the dysregulation of many physiological processes, nowadays, selective antibodies are designed to specifically target CD39 in order to inhibit its activities [27,85].

While the vast majority of clinical trials involving adenosine pathways have mainly evaluated the use of anti-CD73 mAb and $\mathrm{A} 2 \mathrm{aR} / \mathrm{A} 2 \mathrm{bR}$ antagonists $[9,98]$, three agents targeting CD39 were recently developed and included in clinical trials in patients with advanced solid tumors. TTX-030 is one of the newest human monoclonal antibodies, developed by Tizona Therapeutics. Two randomized clinical trials, NCT03884556 and NCT04306900, respectively posted in March 2019 and March 2020, sought to study the safety, tolerability, pharmacokinetics and anti-tumor activity of the TTX-030 antibody as a single therapy and/or in combination with an approved anti-PD-1 immunotherapy (Pembrolizumab/Budigalimab) and/or standard chemotherapies (Docetaxel, Paclitaxel 
and Gemcitabine). Similarly, a CD39 blocking antibody (IPH520) was recently developed by Innate Pharma and entered in a recent clinical trial (NCT04261075) with the objective of studying IPH5201 as a monotherapy or in combination with anti-PDL1 (Durvalumab) and/or anti-CD73 (Oleclumab).

\title{
8. Future Perspectives
}

Adenosine signaling pathway components are currently considered as important targets in the treatment of various cancers [9,98]. Although monotherapies may achieve good results, almost all ongoing clinical trials involving blocking the adenosine pathways include arms in combination with standard chemotherapies or immune check point blocked (ICB) therapies.

Despite the remarkable effects of ICB therapies in several cancers [99-101], only around $30 \%$ of patients responded to ICB as a monotherapy [99-102], supporting the notion that a considerable portion of patients fail to mount protective/beneficial responses. One of the mechanisms associated with immunosuppression following ICB therapy could be dying tumor cells, which would provide immunosuppression due to eATP/adenosine release. Therefore, combining ICB with classical chemotherapies and/or adenosine/CD73 and CD39 blockade may improve the efficacy of these treatments, as well combining ICB with one or more blockade targeting adenosine components. For example, the combination of anti-CD73 with either anti-PD1 or anti-CTLA-4 may have beneficial effects $[98,103,104]$. Given the advances in CAR-T technologies as new tools to fight cancer, $\mathrm{T}$ cells could be alternatively engineered to be deficient in CD73/CD39 or adenosine receptors [105,106], improving their antitumor effector functions.

Altogether, these observations highlight the potential importance of targeting CD73, adenosine components and/or the CD39 pathway. In the near future, we will be able to comprehensively compile data from ongoing clinical trials testing anti-CD73, anti-CD39 and/or other adenosine components alone or in combination with ICB.

Funding: This work was supported by the following grants to V.B.: Associazione Italiana per la Ricerca sul Cancro Grant IG-2017 19784; The Accelerated Award 2018 (Project Id.22794); Ministero della Salute (Ricerca finalizzata [RF-2010-2310438 and RF 2010-2318269]); Fondazione Italiana Sclerosi Multipla (FISM) onlus (cod. 2015/R/04 and 2019/R-Single/053); Fondo per gli investimenti di ricerca di base (FIRB)-2011/13 (no. RBAP10TPXK); Istituto Pasteur Italia-Fondazione Cenci Bolognetti (grant 2014-2016); International Network Institut Pasteur, Paris-“Programmes Transversaux De Recherche" (PTR n. 20-16). E.T. was supported by a postdoctoral fellowship abroad from the AIRC (2018/2020-number: 20934).

Conflicts of Interest: The authors have no conflict of interest to declare.

\author{
Abbreviations \\ regulatory $\mathrm{T}$ cells (Tregs) \\ conventional CD4 $\mathrm{T}$ cells (cCD4 ${ }^{+} \mathrm{T}$ cells) \\ cancer-associated fibroblasts (CAF) \\ multiple sclerosis (MS) \\ tumor-infiltrating (TI) \\ tumor-infiltrating lymphocytes (TILs) \\ natural killer (NK) \\ tumor-associated-macrophages (TAM) \\ tumor-microenvironment (TME) \\ adenosine triphosphate (ATP) \\ adenosine diphosphate (ADP) \\ cyclic adenosine monophosphate (cAMP) \\ extracellular ATP (eATP) \\ immune check point blocked (ICB) \\ single nucleotide polymorphism (SNP)
}




\section{References}

1. Zimmermann, H. 5'-Nucleotidase: Molecular Structure and Functional Aspects. Biochem. J. 1992, 285, 345-365. [CrossRef] [PubMed]

2. Graeff, R.M.; Walseth, T.F.; Fryxell, K.; Branton, W.D.; Lee, H.C. Enzymatic Synthesis and Characterizations of Cyclic GDP-Ribose. A Procedure for Distinguishing Enzymes with ADP-Ribosyl Cyclase Activity. J. Biol. Chem. 1994, 269, 30260-30267. [CrossRef]

3. Robson, S.C.; Sévigny, J.; Zimmermann, H. The E-NTPDase Family of Ectonucleotidases: Structure Function Relationships and Pathophysiological Significance. Purinergic Signal. 2006, 2, 409-430. [CrossRef]

4. Kaczmarek, E.; Koziak, K.; Sévigny, J.; Siegel, J.B.; Anrather, J.; Beaudoin, A.R.; Bach, F.H.; Robson, S.C. Identification and Characterization of CD39/Vascular ATP Diphosphohydrolase. J. Biol. Chem. 1996, 271, 33116-33122. [CrossRef]

5. Enjyoji, K.; Sévigny, J.; Lin, Y.; Frenette, P.S.; Christie, P.D.; Esch, J.S.; Imai, M.; Edelberg, J.M.; Rayburn, H.; Lech, M.; et al. Targeted Disruption of Cd39/ATP Diphosphohydrolase Results in Disordered Hemostasis and Thromboregulation. Nat. Med. 1999, 5, 1010-1017. [CrossRef] [PubMed]

6. Ohta, A.; Sitkovsky, M. Role of G-Protein-Coupled Adenosine Receptors in Downregulation of Inflammation and Protection from Tissue Damage. Nature 2001, 414, 916-920. [CrossRef]

7. Huang, S.; Apasov, S.; Koshiba, M.; Sitkovsky, M. Role of A2a Extracellular Adenosine Receptor-Mediated Signaling in AdenosineMediated Inhibition of T-Cell Activation and Expansion. Blood 1997, 90, 1600-1610. [CrossRef] [PubMed]

8. Wolberg, G.; Zimmerman, T.P.; Hiemstra, K.; Winston, M.; Chu, L.C. Adenosine Inhibition of Lymphocyte-Mediated Cytolysis: Possible Role of Cyclic Adenosine Monophosphate. Science 1975, 187, 957-959. [CrossRef] [PubMed]

9. Moesta, A.K.; Li, X.-Y.; Smyth, M.J. Targeting CD39 in Cancer. Nat. Rev. Immunol. 2020, 20, 739-755. [CrossRef] [PubMed]

10. Ohta, A.; Gorelik, E.; Prasad, S.J.; Ronchese, F.; Lukashev, D.; Wong, M.K.K.; Huang, X.; Caldwell, S.; Liu, K.; Smith, P.; et al. A2A Adenosine Receptor Protects Tumors from Antitumor T Cells. Proc. Natl. Acad. Sci. USA 2006, 103, 13132-13137. [CrossRef]

11. Mittal, D.; Sinha, D.; Barkauskas, D.; Young, A.; Kalimutho, M.; Stannard, K.; Caramia, F.; Haibe-Kains, B.; Stagg, J.; Khanna, K.K.; et al. Adenosine 2B Receptor Expression on Cancer Cells Promotes Metastasis. Cancer Res. 2016, 76, $4372-4382$. [CrossRef] [PubMed]

12. Chen, S.; Akdemir, I.; Fan, J.; Linden, J.; Zhang, B.; Cekic, C. The Expression of Adenosine A2B Receptor on Antigen-Presenting Cells Suppresses CD8+ T-Cell Responses and Promotes Tumor Growth. Cancer Immunol. Res. 2020, 8, 1064-1074. [CrossRef]

13. Sciaraffia, E.; Riccomi, A.; Lindstedt, R.; Gesa, V.; Cirelli, E.; Patrizio, M.; De Magistris, M.T.; Vendetti, S. Human Monocytes Respond to Extracellular CAMP through A2A and A2B Adenosine Receptors. J. Leukoc. Biol. 2014, 96, 113-122. [CrossRef] [PubMed]

14. Mirabet, M.; Herrera, C.; Cordero, O.J.; Mallol, J.; Lluis, C.; Franco, R. Expression of A2B Adenosine Receptors in Human Lymphocytes: Their Role in T Cell Activation. J. Cell Sci. 1999, 112, 491-502. [CrossRef] [PubMed]

15. Di Virgilio, F.; Adinolfi, E. Extracellular Purines, Purinergic Receptors and Tumor Growth. Oncogene 2017, 36, 293-303. [CrossRef]

16. Di Virgilio, F.; Dal Ben, D.; Sarti, A.C.; Giuliani, A.L.; Falzoni, S. The P2 $\times 7$ Receptor in Infection and Inflammation. Immunity 2017, 47, 15-31. [CrossRef]

17. Di Virgilio, F.; Vuerich, M. Purinergic Signaling in the Immune System. Auton. Neurosci. 2015, 191, 117-123. [CrossRef] [PubMed]

18. Ferrari, D.; Chiozzi, P.; Falzoni, S.; Dal Susino, M.; Melchiorri, L.; Baricordi, O.R.; Di Virgilio, F. Extracellular ATP Triggers IL-1 Beta Release by Activating the Purinergic P2Z Receptor of Human Macrophages. J. Immunol. 1997, 159, 1451-1458.

19. Wu, J.; Wang, Y.-C.; Xu, W.-H.; Luo, W.-J.; Wan, F.-N.; Zhang, H.-L.; Ye, D.-W.; Qu, Y.-Y.; Zhu, Y.-P. High Expression of CD39 Is Associated with Poor Prognosis and Immune Infiltrates in Clear Cell Renal Cell Carcinoma. Onco Targets Ther. 2020, 13, 10453-10464. [CrossRef]

20. Hayes, G.M.; Cairns, B.; Levashova, Z.; Chinn, L.; Perez, M.; Theunissen, J.-W.; Liao-Chan, S.; Bermudez, A.; Flory, M.R.; Schweighofer, K.J.; et al. CD39 Is a Promising Therapeutic Antibody Target for the Treatment of Soft Tissue Sarcoma. Am. J. Transl. Res. 2015, 7, 1181-1188.

21. Bastid, J.; Regairaz, A.; Bonnefoy, N.; Déjou, C.; Giustiniani, J.; Laheurte, C.; Cochaud, S.; Laprevotte, E.; Funck-Brentano, E.; Hemon, P.; et al. Inhibition of CD39 Enzymatic Function at the Surface of Tumor Cells Alleviates Their Immunosuppressive Activity. Cancer Immunol. Res. 2015, 3, 254-265. [CrossRef]

22. Häusler, S.F.M.; Montalbán del Barrio, I.; Strohschein, J.; Chandran, P.A.; Engel, J.B.; Hönig, A.; Ossadnik, M.; Horn, E.; Fischer, B.; Krockenberger, M.; et al. Ectonucleotidases CD39 and CD73 on OvCA Cells Are Potent Adenosine-Generating Enzymes Responsible for Adenosine Receptor 2A-Dependent Suppression of T Cell Function and NK Cell Cytotoxicity. Cancer Immunol. Immunother. 2011, 60, 1405-1418. [CrossRef]

23. Simoni, Y.; Becht, E.; Fehlings, M.; Loh, C.Y.; Koo, S.-L.; Teng, K.W.W.; Yeong, J.P.S.; Nahar, R.; Zhang, T.; Kared, H.; et al. Bystander CD8+ T Cells Are Abundant and Phenotypically Distinct in Human Tumour Infiltrates. Nature 2018, 557, 575-579. [CrossRef]

24. Borsellino, G.; Kleinewietfeld, M.; Di Mitri, D.; Sternjak, A.; Diamantini, A.; Giometto, R.; Höpner, S.; Centonze, D.; Bernardi, G.; Dell'Acqua, M.L.; et al. Expression of Ectonucleotidase CD39 by Foxp3+ Treg Cells: Hydrolysis of Extracellular ATP and Immune Suppression. Blood 2007, 110, 1225-1232. [CrossRef]

25. Li, X.-Y.; Moesta, A.K.; Xiao, C.; Nakamura, K.; Casey, M.; Zhang, H.; Madore, J.; Lepletier, A.; Aguilera, A.R.; Sundarrajan, A.; et al. Targeting CD39 in Cancer Reveals an Extracellular ATP- and Inflammasome-Driven Tumor Immunity. Cancer Discov. 2019, 9, 1754-1773. [CrossRef] 
26. Yan, J.; Li, X.-Y.; Roman Aguilera, A.; Xiao, C.; Jacoberger-Foissac, C.; Nowlan, B.; Robson, S.C.; Beers, C.; Moesta, A.K.; Geetha, N.; et al. Control of Metastases via Myeloid CD39 and NK Cell Effector Function. Cancer Immunol. Res. 2020, 8, 356-367. [CrossRef] [PubMed]

27. Zhang, H.; Vijayan, D.; Li, X.-Y.; Robson, S.C.; Geetha, N.; Teng, M.W.L.; Smyth, M.J. The Role of NK Cells and CD39 in the Immunological Control of Tumor Metastases. OncoImmunology 2019, 8, e1593809. [CrossRef] [PubMed]

28. Canale, F.P.; Ramello, M.C.; Núñez, N.; Araujo Furlan, C.L.; Bossio, S.N.; Gorosito Serrán, M.; Tosello Boari, J.; Del Castillo, A.; Ledesma, M.; Sedlik, C.; et al. CD39 Expression Defines Cell Exhaustion in Tumor-Infiltrating CD8+ T Cells. Cancer Res. 2018, 78, 115-128. [CrossRef] [PubMed]

29. Cai, X.-Y.; Wang, X.-F.; Li, J.; Dong, J.-N.; Liu, J.-Q.; Li, N.-P.; Yun, B.; Xia, R.-L.; Qin, J.; Sun, Y.-H. High Expression of CD39 in Gastric Cancer Reduces Patient Outcome Following Radical Resection. Oncol. Lett. 2016, 12, 4080-4086. [CrossRef] [PubMed]

30. Muñóz-Godínez, R.; de Lourdes Mora-García, M.; Weiss-Steider, B.; Montesinos-Montesinos, J.J.; Del Carmen Aguilar-Lemarroy, A.; García-Rocha, R.; Hernández-Montes, J.; Azucena Don-López, C.; Ávila-Ibarra, L.R.; Torres-Pineda, D.B.; et al. Detection of CD39 and a Highly Glycosylated Isoform of Soluble CD73 in the Plasma of Patients with Cervical Cancer: Correlation with Disease Progression. Mediat. Inflamm. 2020, 2020, 1678780. [CrossRef]

31. Cai, X.-Y.; Ni, X.-C.; Yi, Y.; He, H.-W.; Wang, J.-X.; Fu, Y.-P.; Sun, J.; Zhou, J.; Cheng, Y.-F.; Jin, J.-J.; et al. Overexpression of CD39 in Hepatocellular Carcinoma Is an Independent Indicator of Poor Outcome after Radical Resection. Medicine 2016, 95 , e4989. [CrossRef] [PubMed]

32. Ma, X.-L.; Hu, B.; Tang, W.-G.; Xie, S.-H.; Ren, N.; Guo, L.; Lu, R.-Q. CD73 Sustained Cancer-Stem-Cell Traits by Promoting SOX9 Expression and Stability in Hepatocellular Carcinoma. J. Hematol. Oncol. 2020, 13, 11. [CrossRef] [PubMed]

33. Young, A.; Ngiow, S.F.; Barkauskas, D.S.; Sult, E.; Hay, C.; Blake, S.J.; Huang, Q.; Liu, J.; Takeda, K.; Teng, M.W.L.; et al. Co-Inhibition of CD73 and A2AR Adenosine Signaling Improves Anti-Tumor Immune Responses. Cancer Cell 2016, 30, 391-403. [CrossRef] [PubMed]

34. Chen, S.; Fan, J.; Zhang, M.; Qin, L.; Dominguez, D.; Long, A.; Wang, G.; Ma, R.; Li, H.; Zhang, Y.; et al. CD73 Expression on Effector T Cells Sustained by TGF- $\beta$ Facilitates Tumor Resistance to Anti-4-1BB/CD137 Therapy. Nat. Commun. 2019, 10, 150. [CrossRef] [PubMed]

35. Neo, S.Y.; Yang, Y.; Record, J.; Ma, R.; Chen, X.; Chen, Z.; Tobin, N.P.; Blake, E.; Seitz, C.; Thomas, R.; et al. CD73 Immune Checkpoint Defines Regulatory NK Cells within the Tumor Microenvironment. J. Clin. Investig. 2020, 130, 1185-1198. [CrossRef]

36. Wettstein, M.S.; Buser, L.; Hermanns, T.; Roudnicky, F.; Eberli, D.; Baumeister, P.; Sulser, T.; Wild, P.; Poyet, C. CD73 Predicts Favorable Prognosis in Patients with Nonmuscle-Invasive Urothelial Bladder Cancer. Dis. Markers 2015, 2015, 785461. [CrossRef]

37. Chen, Q.; Pu, N.; Yin, H.; Zhang, J.; Zhao, G.; Lou, W.; Wu, W. CD73 Acts as a Prognostic Biomarker and Promotes Progression and Immune Escape in Pancreatic Cancer. J. Cell Mol. Med. 2020, 24, 8674-8686. [CrossRef]

38. Ren, Z.-H.; Lin, C.-Z.; Cao, W.; Yang, R.; Lu, W.; Liu, Z.-Q.; Chen, Y.-M.; Yang, X.; Tian, Z.; Wang, L.-Z.; et al. CD73 Is Associated with Poor Prognosis in HNSCC. Oncotarget 2016, 7, 61690-61702. [CrossRef]

39. Monteiro, I.; Vigano, S.; Faouzi, M.; Treilleux, I.; Michielin, O.; Ménétrier-Caux, C.; Caux, C.; Romero, P.; de Leval, L. CD73 Expression and Clinical Significance in Human Metastatic Melanoma. Oncotarget 2018, 9, 26659-26669. [CrossRef]

40. Kashyap, A.S.; Thelemann, T.; Klar, R.; Kallert, S.M.; Festag, J.; Buchi, M.; Hinterwimmer, L.; Schell, M.; Michel, S.; Jaschinski, F.; et al. Antisense Oligonucleotide Targeting CD39 Improves Anti-Tumor T Cell Immunity. J. Immunother. Cancer $2019,7,67$. [CrossRef]

41. Allard, B.; Longhi, M.S.; Robson, S.C.; Stagg, J. The Ectonucleotidases CD39 and CD73: Novel Checkpoint Inhibitor Targets. Immunol. Rev. 2017, 276, 121-144. [CrossRef]

42. Stagg, J.; Divisekera, U.; McLaughlin, N.; Sharkey, J.; Pommey, S.; Denoyer, D.; Dwyer, K.M.; Smyth, M.J. Anti-CD73 Antibody Therapy Inhibits Breast Tumor Growth and Metastasis. Proc. Natl. Acad. Sci. USA 2010, 107, 1547-1552. [CrossRef]

43. Stagg, J.; Divisekera, U.; Duret, H.; Sparwasser, T.; Teng, M.W.L.; Darcy, P.K.; Smyth, M.J. CD73-Deficient Mice Have Increased Antitumor Immunity and Are Resistant to Experimental Metastasis. Cancer Res. 2011, 71, 2892-2900. [CrossRef]

44. Gallerano, D.; Ciminati, S.; Grimaldi, A.; Piconese, S.; Cammarata, I.; Focaccetti, C.; Pacella, I.; Accapezzato, D.; Lancellotti, F.; Sacco, L.; et al. Genetically Driven CD39 Expression Shapes Human Tumor-Infiltrating CD8 ${ }^{+}$T-Cell Functions. Int. J. Cancer 2020, 147, 2597-2610. [CrossRef]

45. Dang, E.V.; Barbi, J.; Yang, H.-Y.; Jinasena, D.; Yu, H.; Zheng, Y.; Bordman, Z.; Fu, J.; Kim, Y.; Yen, H.-R.; et al. Control of $\mathrm{T}(\mathrm{H}) 17 / \mathrm{T}(\mathrm{Reg})$ Balance by Hypoxia-Inducible Factor 1. Cell 2011, 146, 772-784. [CrossRef]

46. Liao, H.; Hyman, M.C.; Baek, A.E.; Fukase, K.; Pinsky, D.J. CAMP/CREB-Mediated Transcriptional Regulation of Ectonucleoside Triphosphate Diphosphohydrolase 1 (CD39) Expression. J. Biol. Chem. 2010, 285, 14791-14805. [CrossRef]

47. Ostapchuk, Y.O.; Perfilyeva, Y.V.; Kustova, E.A.; Urazalieva, N.T.; Omarbaeva, N.A.; Talaeva, S.G.; Belyaev, N.N. Functional Heterogeneity of Circulating T Regulatory Cell Subsets in Breast Cancer Patients. Breast Cancer 2018, 25, 687-697. [CrossRef] [PubMed]

48. Głowala-Kosińska, M.; Chwieduk, A.; Nieckula, J.; Saduś-Wojciechowska, M.; Grosicki, S.; Rusin, A.; Nowara, E.; Giebel, S. Association of Circulating Regulatory T Cell Number with the Incidence and Prognosis of Diffuse Large B-Cell Lymphoma. Eur. J. Haematol. 2013, 91, 122-128. [CrossRef] [PubMed] 
49. Retseck, J.; Nasr, A.; Lin, Y.; Lin, H.; Mendiratta, P.; Butterfield, L.H.; Tarhini, A.A. Long Term Impact of CTLA4 Blockade Immunotherapy on Regulatory and Effector Immune Responses in Patients with Melanoma. J. Transl. Med. 2018, 16, 184. [CrossRef]

50. Mandapathil, M.; Szczepanski, M.J.; Szajnik, M.; Ren, J.; Lenzner, D.E.; Jackson, E.K.; Gorelik, E.; Lang, S.; Johnson, J.T.; Whiteside, T.L. Increased Ectonucleotidase Expression and Activity in Regulatory T Cells of Patients with Head and Neck Cancer. Clin. Cancer Res. 2009, 15, 6348-6357. [CrossRef]

51. Timperi, E.; Pacella, I.; Schinzari, V.; Focaccetti, C.; Sacco, L.; Farelli, F.; Caronna, R.; Del Bene, G.; Longo, F.; Ciardi, A.; et al. Regulatory T Cells with Multiple Suppressive and Potentially Pro-Tumor Activities Accumulate in Human Colorectal Cancer. Oncoimmunology 2016, 5, e1175800. [CrossRef]

52. Ahlmanner, F.; Sundström, P.; Akeus, P.; Eklöf, J.; Börjesson, L.; Gustavsson, B.; Lindskog, E.B.; Raghavan, S.; Quiding-Järbrink, M. CD39+ Regulatory T Cells Accumulate in Colon Adenocarcinomas and Display Markers of Increased Suppressive Function. Oncotarget 2018, 9, 36993-37007. [CrossRef]

53. Piconese, S.; Timperi, E.; Pacella, I.; Schinzari, V.; Tripodo, C.; Rossi, M.; Guglielmo, N.; Mennini, G.; Grazi, G.L.; Di Filippo, S.; et al. Human OX40 Tunes the Function of Regulatory T Cells in Tumor and Nontumor Areas of Hepatitis C Virus-Infected Liver Tissue. Hepatology 2014, 60, 1494-1507. [CrossRef]

54. Kortekaas, K.E.; Santegoets, S.J.; Sturm, G.; Ehsan, I.; van Egmond, S.L.; Finotello, F.; Trajanoski, Z.; Welters, M.J.P.; van Poelgeest, M.I.E.; van der Burg, S.H. CD39 Identifies the CD4+ Tumor-Specific T-Cell Population in Human Cancer. Cancer Immunol. Res. 2020, 8, 1311-1321. [CrossRef]

55. Schenk, U.; Frascoli, M.; Proietti, M.; Geffers, R.; Traggiai, E.; Buer, J.; Ricordi, C.; Westendorf, A.M.; Grassi, F. ATP Inhibits the Generation and Function of Regulatory T Cells through the Activation of Purinergic P2X Receptors. Sci. Signal. 2011, 4, ra12. [CrossRef]

56. Chalmin, F.; Mignot, G.; Bruchard, M.; Chevriaux, A.; Végran, F.; Hichami, A.; Ladoire, S.; Derangère, V.; Vincent, J.; Masson, D.; et al. Stat3 and Gfi-1 Transcription Factors Control Th17 Cell Immunosuppressive Activity via the Regulation of Ectonucleotidase Expression. Immunity 2012, 36, 362-373. [CrossRef]

57. Gupta, P.K.; Godec, J.; Wolski, D.; Adland, E.; Yates, K.; Pauken, K.E.; Cosgrove, C.; Ledderose, C.; Junger, W.G.; Robson, S.C.; et al. CD39 Expression Identifies Terminally Exhausted CD8+ T Cells. PLoS Pathog. 2015, 11, e1005177. [CrossRef]

58. Qi, Y.; Xia, Y.; Lin, Z.; Qu, Y.; Qi, Y.; Chen, Y.; Zhou, Q.; Zeng, H.; Wang, J.; Chang, Y.; et al. Tumor-Infiltrating CD39+CD8+ T Cells Determine Poor Prognosis and Immune Evasion in Clear Cell Renal Cell Carcinoma Patients. Cancer Immunol. Immunother. 2020, 69, 1565-1576. [CrossRef]

59. Yost, K.E.; Satpathy, A.T.; Wells, D.K.; Qi, Y.; Wang, C.; Kageyama, R.; McNamara, K.L.; Granja, J.M.; Sarin, K.Y.; Brown, R.A.; et al. Clonal Replacement of Tumor-Specific T Cells Following PD-1 Blockade. Nat. Med. 2019, 25, 1251-1259. [CrossRef] [PubMed]

60. Duhen, T.; Duhen, R.; Montler, R.; Moses, J.; Moudgil, T.; de Miranda, N.F.; Goodall, C.P.; Blair, T.C.; Fox, B.A.; McDermott, J.E.; et al. Co-Expression of CD39 and CD103 Identifies Tumor-Reactive CD8 T Cells in Human Solid Tumors. Nat. Commun. 2018, 9 , 2724. [CrossRef]

61. Workel, H.H.; van Rooij, N.; Plat, A.; Spierings, D.C.J.; Fehrmann, R.S.N.; Nijman, H.W.; de Bruyn, M. Transcriptional Activity and Stability of CD39+CD103+CD8+ T Cells in Human High-Grade Endometrial Cancer. Int. J. Mol. Sci. 2020, 21, 3770. [CrossRef]

62. Webb, J.R.; Milne, K.; Watson, P.; Deleeuw, R.J.; Nelson, B.H. Tumor-Infiltrating Lymphocytes Expressing the Tissue Resident Memory Marker CD103 Are Associated with Increased Survival in High-Grade Serous Ovarian Cancer. Clin. Cancer Res. 2014, 20, 434-444. [CrossRef] [PubMed]

63. Kim, H.-D.; Jeong, S.; Park, S.; Lee, Y.J.; Ju, Y.S.; Kim, D.; Song, G.-W.; Lee, J.H.; Kim, S.-Y.; Shin, J.; et al. Implication of CD69+ CD103+ Tissue-Resident-like CD8+ T Cells as a Potential Immunotherapeutic Target for Cholangiocarcinoma. Liver Int. 2021, 41, 764-776. [CrossRef] [PubMed]

64. Vieyra-Lobato, M.R.; Vela-Ojeda, J.; Montiel-Cervantes, L.; López-Santiago, R.; Moreno-Lafont, M.C. Description of CD8+ Regulatory T Lymphocytes and Their Specific Intervention in Graft-versus-Host and Infectious Diseases, Autoimmunity, and Cancer. J. Immunol. Res. 2018, 2018, 3758713. [CrossRef]

65. Noble, A.; Mehta, H.; Lovell, A.; Papaioannou, E.; Fairbanks, L. IL-12 and IL-4 Activate a CD39-Dependent Intrinsic Peripheral Tolerance Mechanism in CD8(+) T Cells. Eur. J. Immunol. 2016, 46, 1438-1448. [CrossRef]

66. Parodi, A.; Battaglia, F.; Kalli, F.; Ferrera, F.; Conteduca, G.; Tardito, S.; Stringara, S.; Ivaldi, F.; Negrini, S.; Borgonovo, G.; et al. CD39 Is Highly Involved in Mediating the Suppression Activity of Tumor-Infiltrating CD8+ T Regulatory Lymphocytes. Cancer Immunol. Immunother. 2013, 62, 851-862. [CrossRef]

67. Schuler, P.J.; Schilling, B.; Harasymczuk, M.; Hoffmann, T.K.; Johnson, J.; Lang, S.; Whiteside, T.L. Phenotypic and Functional Characteristics of CD4+ CD39+ FOXP3+ and CD4+ CD39+ FOXP3neg T-Cell Subsets in Cancer Patients. Eur. J. Immunol. 2012, 42, 1876-1885. [CrossRef]

68. Gerner, M.C.; Ziegler, L.S.; Schmidt, R.L.J.; Krenn, M.; Zimprich, F.; Uyanik-Ünal, K.; Konstantopoulou, V.; Derdak, S.; Del Favero, G.; Schwarzinger, I.; et al. The TGF-b/SOX4 Axis and ROS-Driven Autophagy Co-Mediate CD39 Expression in Regulatory T-Cells. FASEB J. 2020, 34, 8367-8384. [CrossRef]

69. Park, Y.-J.; Ryu, H.; Choi, G.; Kim, B.-S.; Hwang, E.S.; Kim, H.S.; Chung, Y. IL-27 Confers a Protumorigenic Activity of Regulatory T Cells via CD39. Proc. Natl. Acad. Sci. USA 2019, 116, 3106-3111. [CrossRef] 
70. Kochetkova, I.; Golden, S.; Holderness, K.; Callis, G.; Pascual, D.W. IL-35 Stimulation of CD39+ Regulatory T Cells Confers Protection against Collagen II-Induced Arthritis via the Production of IL-10. J. Immunol. 2010, 184, 7144-7153. [CrossRef]

71. Raczkowski, F.; Rissiek, A.; Ricklefs, I.; Heiss, K.; Schumacher, V.; Wundenberg, K.; Haag, F.; Koch-Nolte, F.; Tolosa, E.; Mittrücker, H.-W. CD39 Is Upregulated during Activation of Mouse and Human T Cells and Attenuates the Immune Response to Listeria Monocytogenes. PLoS ONE 2018, 13, e0197151. [CrossRef]

72. Shevchenko, I.; Mathes, A.; Groth, C.; Karakhanova, S.; Müller, V.; Utikal, J.; Werner, J.; Bazhin, A.V.; Umansky, V. Enhanced Expression of CD39 and CD73 on T Cells in the Regulation of Anti-Tumor Immune Responses. Oncoimmunology 2020, $9,1744946$. [CrossRef]

73. Zheng, Y.; Li, Y.; Tang, B.; Zhao, Q.; Wang, D.; Liu, Y.; Guo, M.; Zhao, S.; Qi, Y.; Zhang, Y.; et al. IL-6-Induced CD39 Expression on Tumor-Infiltrating NK Cells Predicts Poor Prognosis in Esophageal Squamous Cell Carcinoma. Cancer Immunol. Immunother. 2020, 69, 2371-2380. [CrossRef]

74. Amadori, A.; Zamarchi, R.; De Silvestro, G.; Forza, G.; Cavatton, G.; Danieli, G.A.; Clementi, M.; Chieco-Bianchi, L. Genetic Control of the CD4/CD8 T-Cell Ratio in Humans. Nat. Med. 1995, 1, 1279-1283. [CrossRef]

75. Orrù, V.; Steri, M.; Sole, G.; Sidore, C.; Virdis, F.; Dei, M.; Lai, S.; Zoledziewska, M.; Busonero, F.; Mulas, A.; et al. Genetic Variants Regulating Immune Cell Levels in Health and Disease. Cell 2013, 155, 242-256. [CrossRef]

76. Roederer, M.; Quaye, L.; Mangino, M.; Beddall, M.H.; Mahnke, Y.; Chattopadhyay, P.; Tosi, I.; Napolitano, L.; Terranova Barberio, M.; Menni, C.; et al. The Genetic Architecture of the Human Immune System: A Bioresource for Autoimmunity and Disease Pathogenesis. Cell 2015, 161, 387-403. [CrossRef]

77. Rissiek, A.; Baumann, I.; Cuapio, A.; Mautner, A.; Kolster, M.; Arck, P.C.; Dodge-Khatami, A.; Mittrücker, H.-W.; Koch-Nolte, F.; Haag, F.; et al. The Expression of CD39 on Regulatory T Cells Is Genetically Driven and Further Upregulated at Sites of Inflammation. J. Autoimmun. 2015, 58, 12-20. [CrossRef]

78. Friedman, D.J.; Künzli, B.M.; A-Rahim, Y.I.; Sevigny, J.; Berberat, P.O.; Enjyoji, K.; Csizmadia, E.; Friess, H.; Robson, S.C. From the Cover: CD39 Deletion Exacerbates Experimental Murine Colitis and Human Polymorphisms Increase Susceptibility to Inflammatory Bowel Disease. Proc. Natl. Acad. Sci. USA 2009, 106, 16788-16793. [CrossRef]

79. Melchiotti, R.; Puan, K.J.; Andiappan, A.K.; Poh, T.Y.; Starke, M.; Zhuang, L.; Petsch, K.; Lai, T.S.; Chew, F.T.; Larbi, A.; et al. Genetic Analysis of an Allergic Rhinitis Cohort Reveals an Intercellular Epistasis between FAM134B and CD39. BMC Med. Genet. 2014, 15, 73. [CrossRef]

80. Timperi, E.; Folgori, L.; Amodio, D.; De Luca, M.; Chiurchiù, S.; Piconese, S.; Di Cesare, S.; Pacella, I.; Martire, C.; Bonatti, G.; et al. Expansion of Activated Regulatory T Cells Inversely Correlates with Clinical Severity in Septic Neonates. J. Allergy Clin. Immunol. 2016, 137, 1617-1620.e6. [CrossRef]

81. Adhikary, S.R.; Cuthbertson, P.; Turner, R.J.; Sluyter, R.; Watson, D. A Single-Nucleotide Polymorphism in the Human ENTPD1 Gene Encoding CD39 Is Associated with Worsened Graft-versus-Host Disease in a Humanized Mouse Model. Immunol. Cell Biol. 2020, 98, 397-410. [CrossRef]

82. Nikolova, M.; Carriere, M.; Jenabian, M.-A.; Limou, S.; Younas, M.; Kök, A.; Huë, S.; Seddiki, N.; Hulin, A.; Delaneau, O.; et al. CD39/Adenosine Pathway Is Involved in AIDS Progression. PLoS Pathog. 2011, 7, e1002110. [CrossRef]

83. Fang, F.; Yu, M.; Cavanagh, M.M.; Hutter Saunders, J.; Qi, Q.; Ye, Z.; Le Saux, S.; Sultan, W.; Turgano, E.; Dekker, C.L.; et al. Expression of CD39 on Activated T Cells Impairs Their Survival in Older Individuals. Cell Rep. 2016, 14, 1218-1231. [CrossRef]

84. Cao, W.; Fang, F.; Gould, T.; Li, X.; Kim, C.; Gustafson, C.; Lambert, S.; Weyand, C.M.; Goronzy, J.J. Ecto-NTPDase CD39 Is a Negative Checkpoint That Inhibits Follicular Helper Cell Generation. J. Clin. Investig. 2020, 130, 3422-3436. [CrossRef]

85. Perrot, I.; Michaud, H.-A.; Giraudon-Paoli, M.; Augier, S.; Docquier, A.; Gros, L.; Courtois, R.; Déjou, C.; Jecko, D.; Becquart, O.; et al. Blocking Antibodies Targeting the CD39/CD73 Immunosuppressive Pathway Unleash Immune Responses in Combination Cancer Therapies. Cell Rep. 2019, 27, 2411-2425.e9. [CrossRef] [PubMed]

86. Jin, D.; Fan, J.; Wang, L.; Thompson, L.F.; Liu, A.; Daniel, B.J.; Shin, T.; Curiel, T.J.; Zhang, B. CD73 on Tumor Cells Impairs Antitumor T-Cell Responses: A Novel Mechanism of Tumor-Induced Immune Suppression. Cancer Res. 2010, 70, $2245-2255$. [CrossRef] [PubMed]

87. Stagg, J.; Beavis, P.A.; Divisekera, U.; Liu, M.C.P.; Möller, A.; Darcy, P.K.; Smyth, M.J. CD73-Deficient Mice Are Resistant to Carcinogenesis. Cancer Res. 2012, 72, 2190-2196. [CrossRef] [PubMed]

88. Yegutkin, G.G.; Marttila-Ichihara, F.; Karikoski, M.; Niemelä, J.; Laurila, J.P.; Elima, K.; Jalkanen, S.; Salmi, M. Altered Purinergic Signaling in CD73-Deficient Mice Inhibits Tumor Progression. Eur. J. Immunol. 2011, 41, 1231-1241. [CrossRef] [PubMed]

89. Wang, L.; Fan, J.; Thompson, L.F.; Zhang, Y.; Shin, T.; Curiel, T.J.; Zhang, B. CD73 Has Distinct Roles in Nonhematopoietic and Hematopoietic Cells to Promote Tumor Growth in Mice. J. Clin. Investig. 2011, 121, 2371-2382. [CrossRef] [PubMed]

90. Sun, X.; Han, L.; Seth, P.; Bian, S.; Li, L.; Csizmadia, E.; Junger, W.G.; Schmelzle, M.; Usheva, A.; Tapper, E.B.; et al. Disordered Purinergic Signaling and Abnormal Cellular Metabolism Are Associated with Development of Liver Cancer in Cd39/ENTPD1 Null Mice. Hepatology 2013, 57, 205-216. [CrossRef]

91. Sattler, C.; Steinsdoerfer, M.; Offers, M.; Fischer, E.; Schierl, R.; Heseler, K.; Däubener, W.; Seissler, J. Inhibition of T-Cell Proliferation by Murine Multipotent Mesenchymal Stromal Cells Is Mediated by CD39 Expression and Adenosine Generation. Cell Transplant. 2011, 20, 1221-1230. [CrossRef] [PubMed] 
92. Yang, R.; Elsaadi, S.; Misund, K.; Abdollahi, P.; Vandsemb, E.N.; Moen, S.H.; Kusnierczyk, A.; Slupphaug, G.; Standal, T.; Waage, A.; et al. Conversion of ATP to Adenosine by CD39 and CD73 in Multiple Myeloma Can Be Successfully Targeted Together with Adenosine Receptor A2A Blockade. J. Immunother. Cancer 2020, 8, e000610. [CrossRef]

93. Deaglio, S.; Dwyer, K.M.; Gao, W.; Friedman, D.; Usheva, A.; Erat, A.; Chen, J.-F.; Enjyoji, K.; Linden, J.; Oukka, M.; et al. Adenosine Generation Catalyzed by CD39 and CD73 Expressed on Regulatory T Cells Mediates Immune Suppression. J. Exp. Med. 2007, 204, 1257-1265. [CrossRef]

94. Sun, X.; Wu, Y.; Gao, W.; Enjyoji, K.; Csizmadia, E.; Müller, C.E.; Murakami, T.; Robson, S.C. CD39/ENTPD1 Expression by CD4+Foxp3+ Regulatory T Cells Promotes Hepatic Metastatic Tumor Growth in Mice. Gastroenterology 2010, 139, $1030-1040$. [CrossRef] [PubMed]

95. Enjyoji, K.; Kotani, K.; Thukral, C.; Blumel, B.; Sun, X.; Wu, Y.; Imai, M.; Friedman, D.; Csizmadia, E.; Bleibel, W.; et al. Deletion of Cd39/Entpd1 Results in Hepatic Insulin Resistance. Diabetes 2008, 57, 2311-2320. [CrossRef] [PubMed]

96. Lanser, A.J.; Rezende, R.M.; Rubino, S.; Lorello, P.J.; Donnelly, D.J.; Xu, H.; Lau, L.A.; Dulla, C.G.; Caldarone, B.J.; Robson, S.C.; et al. Disruption of the ATP/Adenosine Balance in CD39-/- Mice Is Associated with Handling-Induced Seizures. Immunology 2017, 152, 589-601. [CrossRef] [PubMed]

97. Nardi-Schreiber, A.; Sapir, G.; Gamliel, A.; Kakhlon, O.; Sosna, J.; Gomori, J.M.; Meiner, V.; Lossos, A.; Katz-Brull, R. Defective ATP Breakdown Activity Related to an ENTPD1 Gene Mutation Demonstrated Using 31P NMR Spectroscopy. Chem. Commun. 2017, 53, 9121-9124. [CrossRef] [PubMed]

98. Thompson, E.A.; Powell, J.D. Inhibition of the Adenosine Pathway to Potentiate Cancer Immunotherapy: Potential for Combinatorial Approaches. Annu. Rev. Med. 2021, 72, 331-348. [CrossRef]

99. Borghaei, H.; Paz-Ares, L.; Horn, L.; Spigel, D.R.; Steins, M.; Ready, N.E.; Chow, L.Q.; Vokes, E.E.; Felip, E.; Holgado, E.; et al. Nivolumab versus Docetaxel in Advanced Nonsquamous Non-Small-Cell Lung Cancer. N. Engl. J. Med. 2015, 373, 1627-1639. [CrossRef]

100. Sharma, P.; Allison, J.P. The Future of Immune Checkpoint Therapy. Science 2015, 348, 56-61. [CrossRef]

101. Topalian, S.L.; Hodi, F.S.; Brahmer, J.R.; Gettinger, S.N.; Smith, D.C.; McDermott, D.F.; Powderly, J.D.; Carvajal, R.D.; Sosman, J.A.; Atkins, M.B.; et al. Safety, Activity, and Immune Correlates of Anti-PD-1 Antibody in Cancer. N. Engl. J. Med. 2012, 366, 2443-2454. [CrossRef] [PubMed]

102. Topalian, S.L.; Drake, C.G.; Pardoll, D.M. Immune Checkpoint Blockade: A Common Denominator Approach to Cancer Therapy. Cancer Cell 2015, 27, 450-461. [CrossRef] [PubMed]

103. Hay, C.M.; Sult, E.; Huang, Q.; Mulgrew, K.; Fuhrmann, S.R.; McGlinchey, K.A.; Hammond, S.A.; Rothstein, R.; Rios-Doria, J.; Poon, E.; et al. Targeting CD73 in the Tumor Microenvironment with MEDI9447. Oncoimmunology 2016, 5, e1208875. [CrossRef]

104. Allard, B.; Pommey, S.; Smyth, M.J.; Stagg, J. Targeting CD73 Enhances the Antitumor Activity of Anti-PD-1 and Anti-CTLA-4 MAbs. Clin. Cancer Res. 2013, 19, 5626-5635. [CrossRef] [PubMed]

105. Cekic, C.; Linden, J. Adenosine A2A Receptors Intrinsically Regulate CD8+ T Cells in the Tumor Microenvironment. Cancer Res. 2014, 74, 7239-7249. [CrossRef]

106. Kjaergaard, J.; Hatfield, S.; Jones, G.; Ohta, A.; Sitkovsky, M. A2A Adenosine Receptor Gene Deletion or Synthetic A2A Antagonist Liberate Tumor-Reactive CD8+ T Cells from Tumor-Induced Immunosuppression. J. Immunol. 2018, 201, 782-791. [CrossRef] [PubMed] 